\title{
Lack of association between a functional polymorphism (rs1800796) in the interleukin-6 gene promoter and lung cancer
}

Weihua Wang ${ }^{*}$, Jie Chen, Feng Zhao, Burong Zhang and Hongsheng Yu

\begin{abstract}
Background: A number of studies have examined the association between interleukin-6 (IL-6) rs1800796 polymorphism and risk of lung cancer but revealed inconsistent results. The aim of this study was to clarify the association between IL-6 rs1800796 polymorphism and risk of lung cancer.
\end{abstract}

Methods: Literature databases including PubMed, Embase and CNKI were searched up to January 2014. The pooled odds ratios (ORs) with 95\% confidence intervals (Cls) under co-dominant model, dominant model and recessive model were estimated using random-effects model.

Results: A total of seven studies, including 2691 lung cancer cases and 3067 controls, were included in the meta-analysis. The results suggested that IL-6 rs 1800796 polymorphism was not associated with risk of lung cancer under homogeneous co-dominant model $(\mathrm{OR}=1.06,95 \% \mathrm{Cl}=0.73-1.54)$, heterogeneous co-dominant model $(\mathrm{OR}=1.24,95 \% \mathrm{Cl}=0.96-1.60)$, dominant model $(O R=1.23,95 \% \mathrm{Cl}=0.95-1.58)$ and recessive model $(\mathrm{OR}=0.96,95 \% \mathrm{Cl}=0.70-1.32)$. The association was still not significant in either never-smokers $(\mathrm{OR}=1.19,95 \% \mathrm{Cl}=0.95-1.48)$ or ever-smokers $(\mathrm{OR}=1.73,95 \% \mathrm{Cl}=0.89-3.36)$.

Conclusion: The present meta-analysis suggested that there was no association between $/ L-6$ rs 1800796 polymorphism and lung cancer, which was independent of smoking status.

Virtual Slides: The virtual slide(s) for this article can be found here: http://www.diagnosticpathology.diagnomx.eu/vs/ 1060061508127855

Keywords: Interleukin-6, Lung cancer, Polymorphism, Meta-analysis

\section{Background}

Lung cancer has become a major public health issue worldwide, which accounts for $13 \%$ of the total cancer cases and $18 \%$ of total deaths in 2008 [1]. To date, the potential mechanism of lung carcinogenesis is not clear. Although it is established that cigarette smoking is one of the most important risk factors causing lung cancer, only $10-15 \%$ of heavy tobacco smokers ultimately develop lung cancer [2]. This evidence suggests that genetic factors may play an important role in the development of lung cancer.

Several studies suggested that chronic inflammation predisposes individuals to different types of cancer, including lung cancer. Interleukin-6 (IL-6) is a major cytokine that is known to affect immune response, which is

\footnotetext{
*Correspondence: wangweihua2014@126.com
The Affiliated Hospital of Medical College of Ningbo University, Ningbo

* Correspondence: wangweihua2014@126.com
The Affiliated Hospital of Medical College of Ningbo University, Ningbo 315020 Zhejiang, China
}

(c) 2014 Wang et al.; licensee BioMed Central Ltd. This is an Open Access article distributed under the terms of the Creative Commons Attribution License (http://creativecommons.org/licenses/by/4.0), which permits unrestricted use, distribution, and reproduction in any medium, provided the original work is properly credited. The Creative Commons Public Domain Dedication waiver (http://creativecommons.org/publicdomain/zero/1.0/) applies to the data made available in this article unless otherwise stated.

expressed in tumor-infiltrating cells. IL- 6 plays a key role in cell survival, proliferation and apoptosis [3]. Three functional polymorphisms (rs1800795 [-174G > C], rs1800796 $[-572 \mathrm{C}>\mathrm{G}$ or $-634 \mathrm{C}>\mathrm{G}]$ and rs10499563 [-6331 $\mathrm{T}>\mathrm{C}]$ ) associated with $I L-6$ transcription activity have been identified in the $I L-6$ promoter region. To date, a great number of studies have investigated the association between $I L-6$ rs1800795 polymorphism and lung cancer, and two metaanalyses [4,5] demonstrated that IL-6 rs1800795 polymorphism was not associated with risk of lung cancer. In addition, some studies suggested that $I L-6$ rs1800796 might be associated with risk of lung cancer; however, the results have been inconsistent [6-11]. To our knowledge, no metaanalysis has been performed to address this topic.

Therefore, in the present study, we aimed to perform a meta-analysis to clarify the association between $I L-6$ rs1800796 polymorphism and risk of lung cancer. 


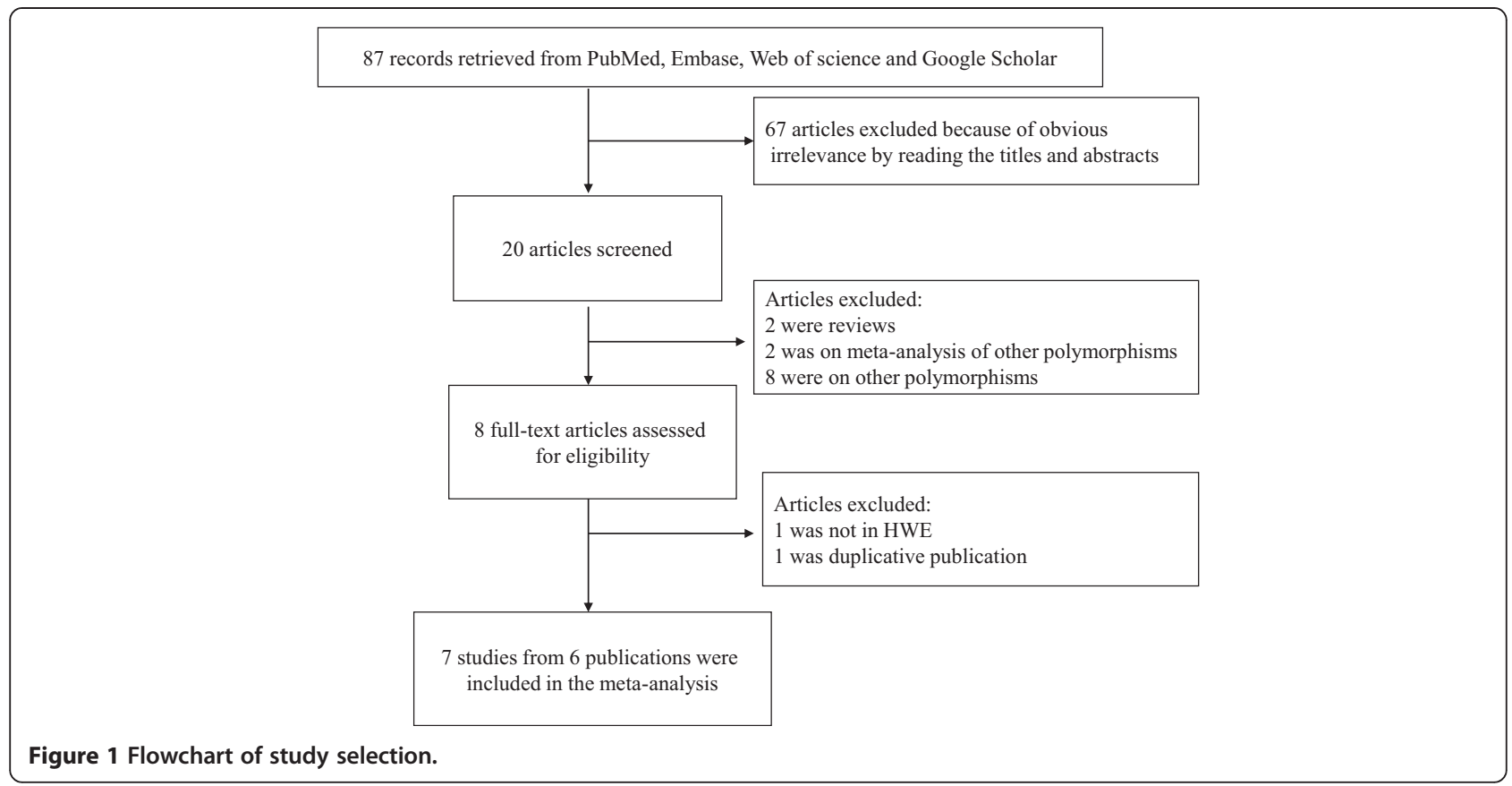

\section{Methods}

\section{Literature and search strategy}

PubMed, EMBASE, and CNKI databases were searched for eligible publications. We used the following key words to identify the potential studies: (Interleukin-6 OR IL-6) and (variant OR variation OR polymorphism OR genotype) and lung cancer. Publication language was restricted to English or Chinese. We also hand-searched the reference lists of retrieved article. If duplicative publications existed, only the study with the large sample size was included. The last literature search was on January 1, 2014.

\section{Inclusion criteria and data extraction}

The inclusion criteria for the studies included: (1) evaluated the association of $I L-6$ rs1800796 polymorphism with lung cancer; (2) used case-control or cohort design; and (3) provided sufficient data for calculation of odds ratio (OR) with $95 \%$ confidence interval (CI). The extracted information from each study included: (1) name of the first author; (2) year of publication; (3) country of origin; (4) sample sizes of cases and controls; (5) genotype distributions of cases and controls; and (6) whether the variant was in Hardy Weinberg Equilibrium (HWE) in controls. Two authors (Weihua Wang and Jie Chen) independently searched articles and extracted the data. The third person was asked if they have different opinions.

\section{Statistical analysis}

The association between IL-6 rs1800796 polymorphism and risk of lung cancer was estimated by calculation of pooled OR and 95\%CI under a co-dominant, a dominant, and a recessive model, respectively. $Z$ test was used to determine the significance of pooled OR $(p<0.05$ was considered statistically significant). The between-study heterogeneity was evaluated by $\mathrm{Q}$ test and and $I^{2}$ statistic [12]. A random- [13] or fixed- [14] effects model was

Table 1 Characteristics of the included studies of the association between IL-6 rs1800796 variant and lung cancer

\begin{tabular}{|c|c|c|c|c|c|c|c|c|c|c|c|}
\hline \multirow[t]{2}{*}{ Study } & \multirow[t]{2}{*}{ Country } & \multirow[t]{2}{*}{ Ethnicity } & \multicolumn{2}{|c|}{ Sample size } & \multicolumn{3}{|c|}{$\begin{array}{l}\text { Genotype frequency } \\
\text { in cases }\end{array}$} & \multicolumn{3}{|c|}{$\begin{array}{l}\text { Genotype frequency } \\
\text { in controls }\end{array}$} & \multirow[t]{2}{*}{$P_{\text {HWE }}$} \\
\hline & & & Cases & Controls & GG & GC & $\mathrm{CC}$ & GG & GC & $\mathrm{CC}$ & \\
\hline Su, $2010[6]$ & China & East Asian & 363 & 370 & 193 & 156 & 14 & 233 & 117 & 20 & 0.30 \\
\hline Lim, 2011 [7] & Singapore & East Asian & 298 & 718 & 163 & 123 & 12 & 449 & 231 & 38 & 0.25 \\
\hline Bai, 2013 [8] & China & East Asian & 193 & 210 & 86 & 89 & 18 & 125 & 69 & 16 & 0.15 \\
\hline Chen, 2013 (discovery group) [9] & China & East Asian & 622 & 614 & 349 & 229 & 44 & 309 & 252 & 53 & 0.87 \\
\hline Chen, 2013 (validation group) [9] & China & East Asian & 615 & 638 & 333 & 245 & 37 & 321 & 263 & 54 & 0.99 \\
\hline Liang, 2013 [10] & China & East Asian & 138 & 138 & 100 & 29 & 9 & 105 & 30 & 3 & 0.62 \\
\hline Kiyohara, 2014 [11] & Japan & East Asian & 462 & 379 & 259 & 175 & 28 & 250 & 116 & 13 & 0.92 \\
\hline
\end{tabular}

$P_{\text {HWE, }} p$ value for Hardy-Weinberg Equilibrium test in controls. 


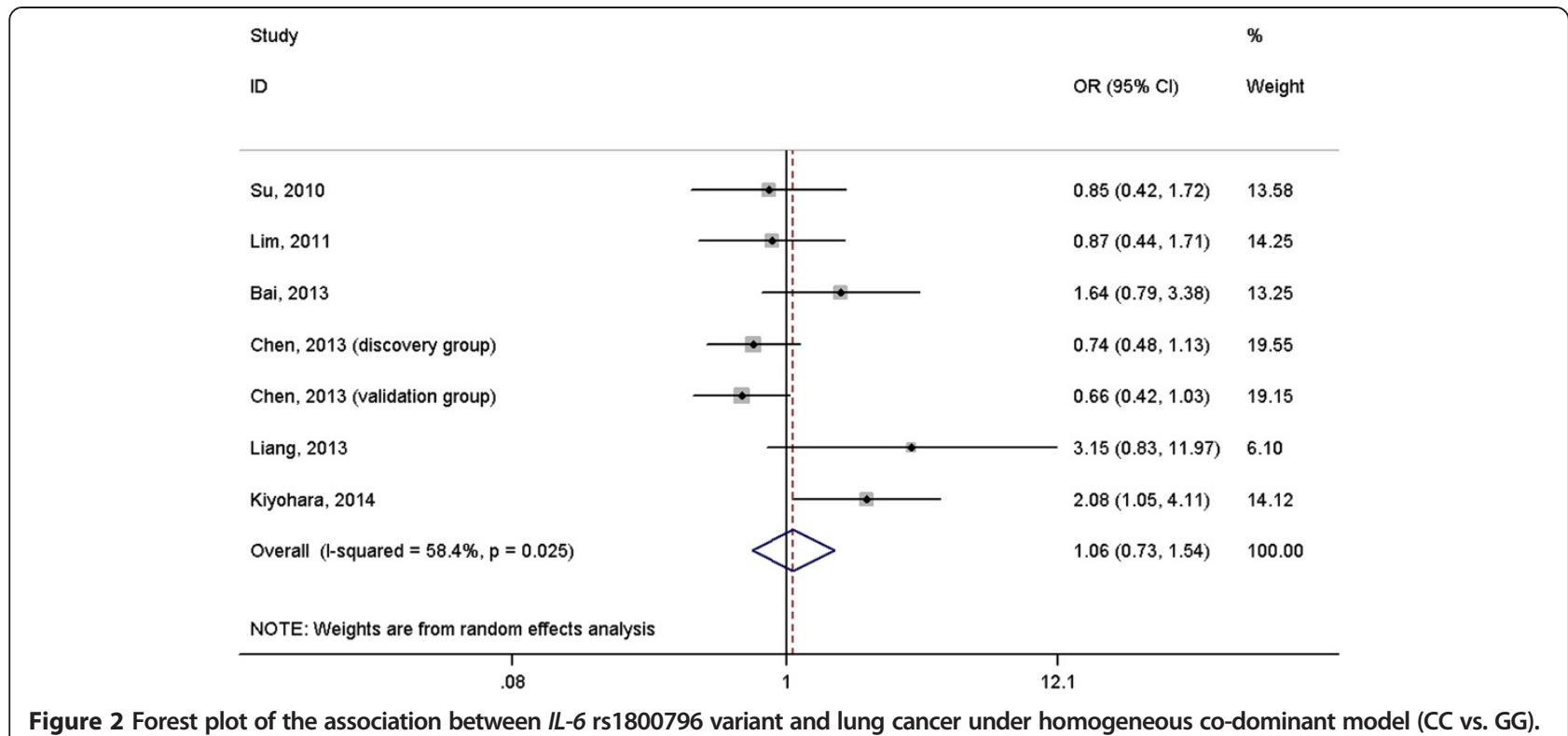

performed to calculate pooled OR in the presence ( $p \leq$ $0.10)$ or absence $(p>0.10)$ of heterogeneity, respectively. Subgroup analysis by whether the subjects smoke was performed. Begg's test [15] was performed to assess publication bias $(p<0.05$ was considered statistically significant). STATA version 11 (StataCorp LP, College Station, TX, USA) was applied to perform data analysis.

\section{Results}

\section{Characteristics of the studies}

After literature search, a total of 87 publications were identified. 67 articles were excluded because of obvious irrelevance after reading abstract or title. In addition, two reviews, two articles on meta-analysis of other polymorphisms and eight articles on other polymorphisms were excluded. Then, one article not in HWE [16] and one duplicated publication [17] were further excluded. At last, a total of seven studies from six publications were included in the meta-analysis (Figure 1). Of seven studies, five were conducted in China, one was conducted in Singapore, and one was conducted in Japan. All study populations were East Asians. The polymorphism in all the included studies was in HWE in controls (all $P>0.05$ ). The characteristics of all the included studies are listed in Table 1.

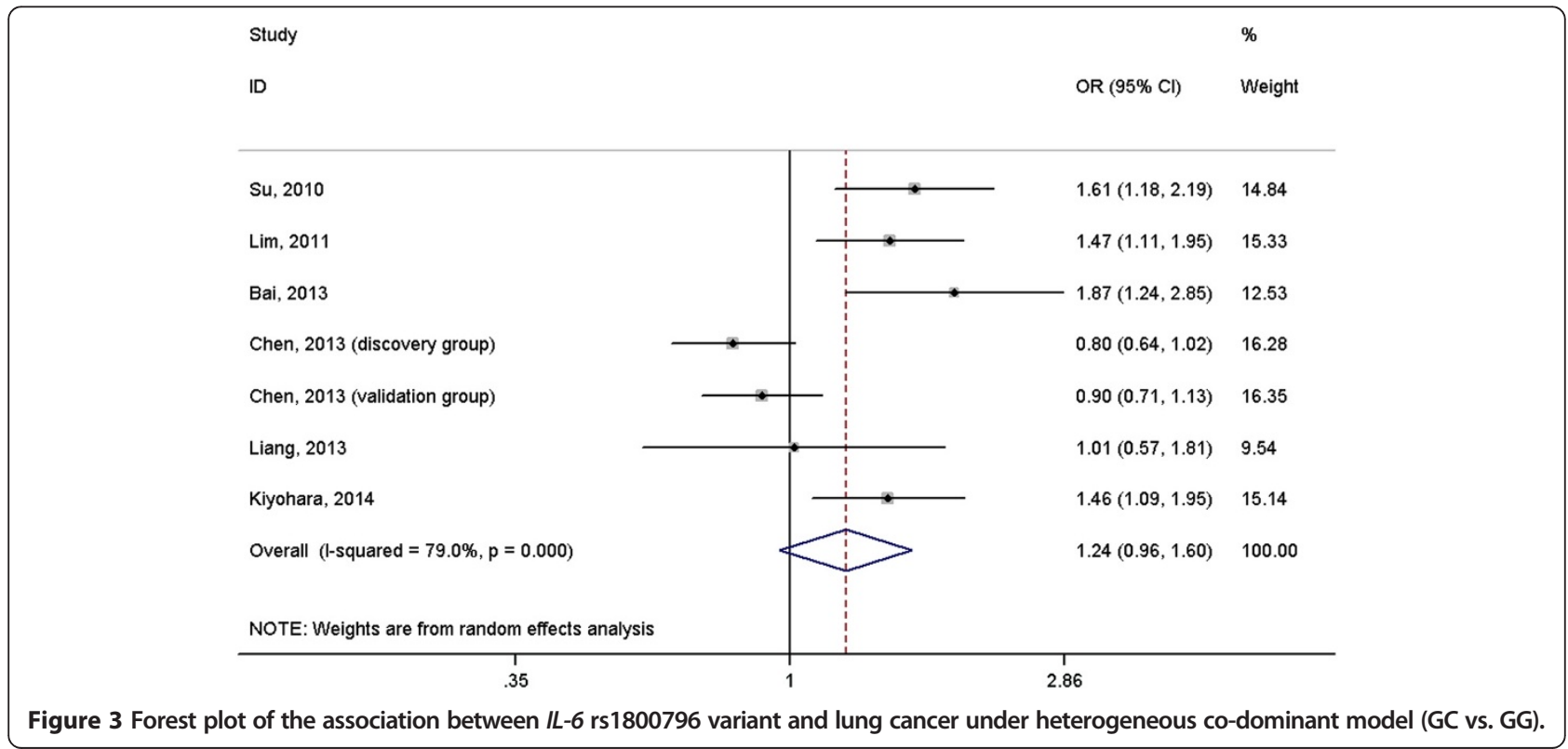




\section{Meta-analysis results}

A total of 2691 cases with lung cancer and 3067 normal controls were included in the meta-analysis. The results suggested that $I L-6$ rs1800796 polymorphism was not associated with risk of lung cancer under homogeneous codominant model $(\mathrm{OR}=1.06,95 \% \mathrm{CI}=0.73-1.54$, Figure 2$)$, heterogeneous co-dominant model $(\mathrm{OR}=1.24,95 \% \mathrm{CI}=$ $0.96-1.60$, Figure 3), dominant model $(\mathrm{OR}=1.23,95 \% \mathrm{CI}=$ $0.95-1.58$, Figure 4), recessive model $(\mathrm{OR}=0.96,95 \% \mathrm{CI}=$ $0.70-1.32$, Figure 5$)$ and allelic model $(\mathrm{OR}=1.15,95 \% \mathrm{CI}=$ 0.95-1.41, Figure 6). Besides using raw genotype data, we also pooled the results adjusted for most common confounding factors under co-dominant model. The nonsignificant association did not change (homogeneous codominant model: $\mathrm{OR}=0.94,95 \% \mathrm{CI}=0.78-1.14$; heterogeneous co-dominant model: $\mathrm{OR}=1.21,95 \% \mathrm{CI}=0.92-1.59$ ).

Cigarette smoking is a most important risk factor for lung cancer, and it may modify the association between IL-6 rs1800796 polymorphism and risk of lung cancer, the subgroup analysis stratified by smoking status (no vs. yes) was performed. However, the association was still not significant in either never-smokers $(\mathrm{OR}=1.19,95 \% \mathrm{CI}=0.95$ 1.48, Additional file 1: Figure S1) or ever-smokers (OR = $1.73,95 \% \mathrm{CI}=0.89-3.36$, Additional file 2: Figure S2).

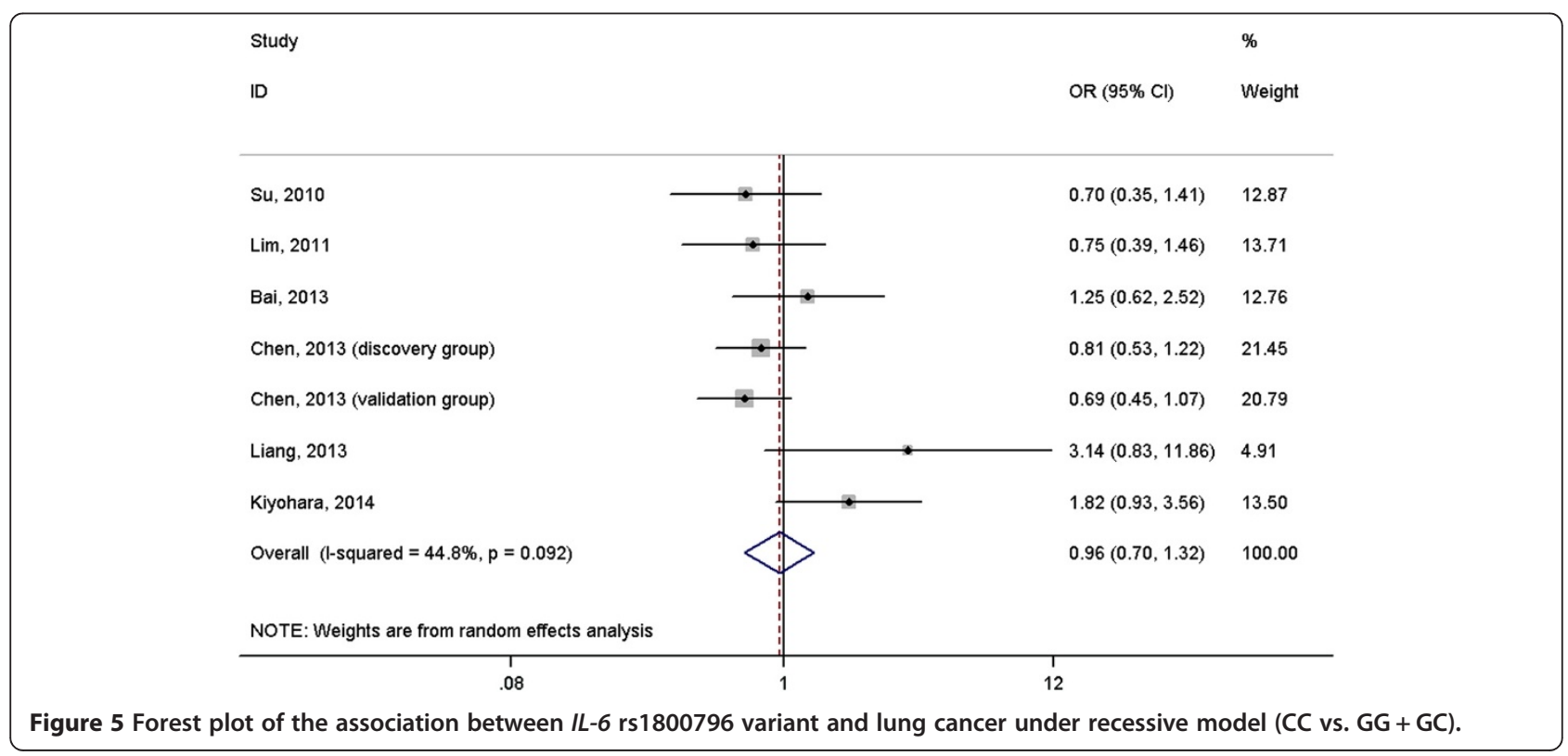




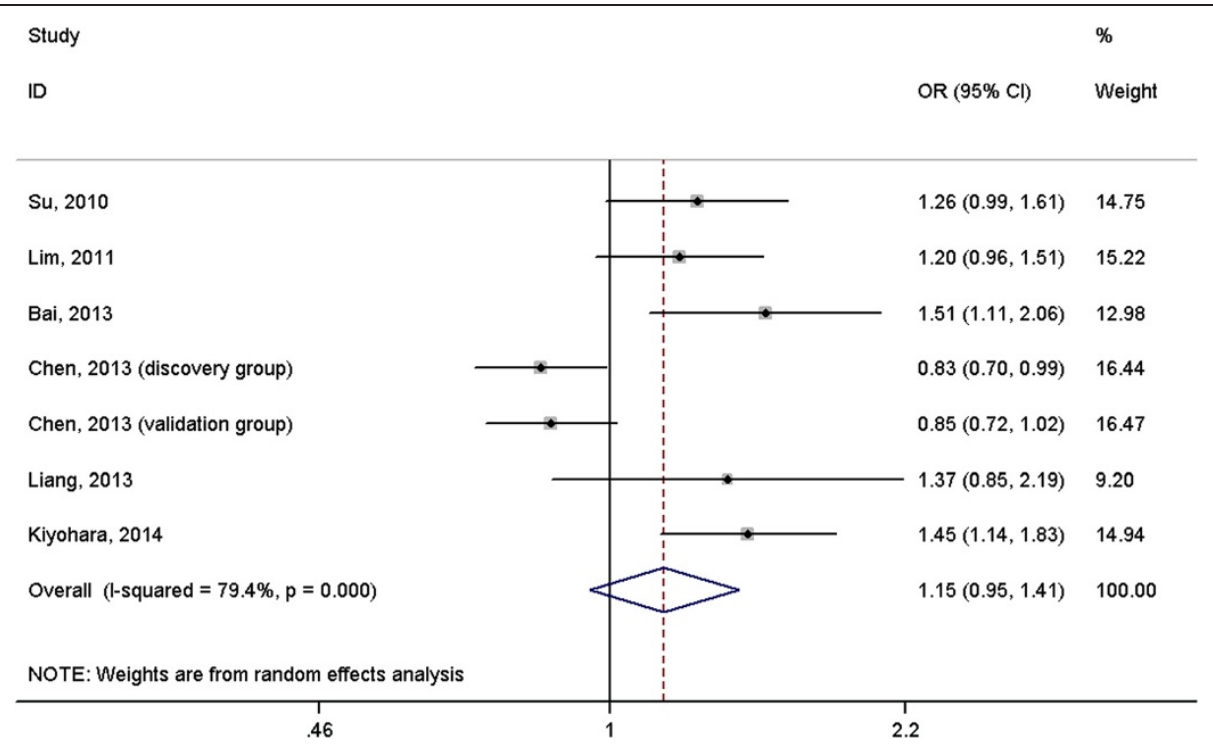

Figure 6 Forest plot of the association between IL-6 rs1800796 variant and lung cancer under allelic model (C vs. G).

Since there was significant between-study heterogeneity for association between IL-6 rs1800796 polymorphism and risk of lung cancer under all genetic models, we performed a meta-regression analysis to explore source of heterogeneity. We introduced variables including publication year, genotype methods, sample size in cases and controls. However, these variables cannot explain the source of heterogeneity.

\section{Potential publication bias}

No publication bias was detected for association between IL-6 rs1800796 polymorphism and risk of lung cancer under all genetic models using the Begg's test $(P=0.133$ for homogeneous co-dominant model; $P=0.230$ for heterogeneous co-dominant model; $P=0.230$ for dominant model; $P=0.230$ for recessive model; $P=0.368$ for allelic model).

\section{Discussion}

The present meta-analysis demonstrated that $I L-6$ rs1800796 polymorphism was not associated with risk of lung cancer under all genetic models. In the subgroup analysis, the non-significant association remained in either neversmokers or smokers.

A previous meta-analysis reported that there was no significant association between IL-6 level and lung cancer risk [18]. However, higher level of IL-6 is suggested to be associated with risk of coronary heart disease [19] and type 2 diabetes [20]. In regards to the functional polymorphism rs1800796 in the IL-6 gene, it was only found to be associated with risk of type 2 diabetes [21], but not with coronary heart disease [22].

It is consistent that rs 1800795 polymorphism was not associated nearly all types of cancers, including colorectal
[23], prostate [24], gastric [25] and breast cancers [26]. But rs1800796 polymorphism was found to be associated with prostate [24] cancer but not with gastric cancer [25]. Based on 2691 cases with lung cancer and 3067 normal controls, we did find significant association between rs1800796 polymorphism and lung cancer.

Heterogeneity may potentially affect the interpretation of the results. Heterogeneity may be attributed to the potential confounding resulted from publication time, sample sizes, measurement errors, or the interaction with other risk factors. In our study, there was significant betweenstudy heterogeneity for association between $I L-6$ rs 1800796 polymorphism and risk of lung cancer under all genetic models. However, meta-regression analysis in consideration of the potential confounders did not address the heterogeneity.

There are several limitations in the present study. First, there might be effects of gene-gene and gene-environment interactions [27-29] but we can not address this because the individual studies did not provide the related data. Second, the sample size in the subgroups was limited and the results should be interpreted with caution. Third, we only assessed one polymorphism in the IL-6 gene, therefore, we can not rule out the possibility that other polymorphisms or haplotypes in this gene might be implicated in the development of lung cancer. Fourth, all the six papers we selected were from East Asia. Thus, the conclusion should not be generalized to other ethnic populations.

\section{Conclusions}

In conclusions, the results of our meta-analysis indicated that there was no significant association between $I L-6$ 
rs1800796 polymorphism and risk of lung cancer, and the non-significant association was independent of whether the individuals smoked cigarettes.

\section{Additional files}

Additional file 1: Forest plot of the association between IL-6 rs1800796 variant and lung cancer in never-smokers with adjustment for potential confounders (dominant model: CC+GC vs. GG).

Additional file 2: Forest plot of the association between IL-6 rs1800796 variant and lung cancer in smokers with adjustment for potential confounders (dominant model: $\mathrm{CC}+\mathrm{GC}$ vs. GG).

\section{Competing interests}

The authors declare that they have no competing interests.

\section{Authors' contributions}

WW and JC designed the study and drafted the manuscript. JC and FZ searched the databases and extracted the data. BZ and HY performed the statistical analysis. All authors read, revised and approved the final manuscript.

\section{Received: 5 May 2014 Accepted: 22 June 2014}

Published: 1 July 2014

\section{References}

1. Jemal A, Bray F, Center MM, Ferlay J, Ward E, Forman D: Global cancer statistics. CA Cancer J Clin 2011, 61:69-90.

2. Toh CK, Gao F, Lim WT, Leong SS, Fong KW, Yap SP, Hsu AA, Eng P, Koong HN, Thirugnanam A, Tan EH: Never-smokers with lung cancer: epidemiologic evidence of a distinct disease entity. J Clin Oncol 2006, 24:2245-2251.

3. Kishimoto T: Interleukin-6: from basic science to medicine-40 years in immunology. Annu Rev Immunol 2005, 23:1-21.

4. Xu B, Niu XB, Wang ZD, Cheng W, Tong N, Mi YY, Min ZC, Tao J, Li PC, Zhang W, Wu HF, Zhang ZD, Wang ZJ, Hua LX, Feng NH, Wang XR: IL-6174G > C polymorphism and cancer risk: a meta-analysis involving 29,377 cases and 37,739 controls. Mol Biol Rep 2011, 38:2589-2596.

5. Peng WJ, He Q, Yang JX, Wang BX, Lu MM, Wang S, Wang J: Meta-analysis of association between cytokine gene polymorphisms and lung cancer risk. Mol Biol Rep 2012, 39:5187-5194.

6. Su M: Interleukin 6-634 and interleukin 1 $\beta-31$ gene polymorphisms and lung cancer risk in female non-smokers. Master Dissertation of Chinese Medical Sciences University. 2011. in Chinese.

7. Lim WY, Chen Y, Ali SM, Chuah KL, Eng P, Leong SS, Lim E, Lim TK, Ng AW, Poh WT, Tee A, Teh M, Salim A, Seow A: Polymorphisms in inflammatory pathway genes, host factors and lung cancer risk in Chinese female never-smokers. Carcinogenesis 2011, 32:522-529.

8. Bai L, Yu H, Wang H, Su H, Zhao J, Zhao Y: Genetic single-nucleotide polymorphisms of inflammation-related factors associated with risk of lung cancer. Med Oncol 2013, 30:414.

9. Chen J, Liu RY, Yang L, Zhao J, Zhao X, Lu D, Yi N, Han B, Chen XF, Zhang K, He J, Lei Z, Zhou Y, Pasche B, Li X, Zhang HT: A two-SNP IL-6 promoter haplotype is associated with increased lung cancer risk. J Cancer Res Clin Oncol 2013, 139:231-242

10. Liang J, Liu X, Bi Z, Yin B, Xiao J, Liu H, Li Y: Relationship between gene polymorphisms of two cytokine genes (TNF- $\alpha$ and IL-6) and occurring of lung cancers in the ethnic group Han of China. Mol Biol Rep 2013, 40:1541-1546.

11. Kiyohara C, Horiuchi T, Takayama K, Nakanishi Y: Genetic polymorphisms involved in the inflammatory response and lung cancer risk: A casecontrol study in Japan. Cytokine 2014, 65:88-94.

12. Higgins JP, Thompson SG, Deeks JJ, Altman DG: Measuring inconsistency in meta-analyses. BMJ 2003, 327:557-560.

13. DerSimonian R, Laird N: Meta-analysis in clinical trials. Control Clin Trials 1986, 7:177-188.

14. Mantel N, Haenszel W: Statistical aspects of the analysis of data from retrospective studies of disease. J Natl Cancer Inst 1959, 22:719-748.
15. Begg CB, Mazumdar M: Operating characteristics of a rank correlation test for publication bias. Biometrics 1994, 50:1088-1101.

16. Liu X, Li Y, Liang J, Sun D, Dai Y, Cao B: The associaiton of interleukin-6 gene polymorphism and lung cancer. Chin J Clin Oncol 2007, 34:562-565 (in Chinese).

17. Seow A, Ng DP, Choo S, Eng P, Poh WT, Ming T, Wang YT: Joint effect of asthma/atopy and an IL-6 gene polymorphism on lung cancer risk among lifetime non-smoking Chinese women. Carcinogenesis 2006, 27:1240-1244

18. Zhou B, Liu J, Wang ZM, Xi T: C-reactive protein, interleukin 6 and lung cancer risk: a meta-analysis. PLoS One 2012, 7:e43075.

19. Kaptoge S, Seshasai SR, Gao P, Freitag DF, Butterworth AS, Borglykke A, Di Angelantonio E, Gudnason V, Rumley A, Lowe GD, Jørgensen T, Danesh J: Inflammatory cytokines and risk of coronary heart disease: new prospective study and updated meta-analysis. Eur Heart J 2014, 35:578-589.

20. Wang X, Bao W, Liu J, Ouyang YY, Wang D, Rong S, Xiao X, Shan ZL, Zhang Y, Yao P, Liu LG: Inflammatory markers and risk of type 2 diabetes: a systematic review and meta-analysis. Diabetes Care 2013, 36:166-175.

21. Yin YW, Sun $Q Q$, Zhang BB, Hu AM, Liu HL, Wang Q, Zeng YH, Xu RJ, Zhang ZD, Zhang ZG: Association between the interleukin- 6 gene -572 C/G polymorphism and the risk of type 2 diabetes mellitus: a meta-analysis of 11,681 subjects. Ann Hum Genet 2013, 77:106-114.

22. Zheng GH, Chen HY, Xiong SQ: Polymorphisms of $-174 \mathrm{G}>\mathrm{C}$ and $-572 \mathrm{G}>$ $C$ in the interleukin 6 (IL-6) gene and coronary heart disease risk: a meta-analysis of 27 research studies. PLoS One 2012, 7:e34839.

23. Hu JJ, Wang ZT, Zhong J: Lack of association between the interleukin 6 gene $-174 \mathrm{G}>$ C polymorphism and colorectal cancer: evidence from a meta-analysis. Genet Mol Res 2013, 12:2205-2214.

24. Magalhães JF, Cortinhas AJ, Albuquerque CM, Baptista CS, Ribeiro R, Viegas C, Matos A, Machado J, Pires MA, Guedes-Pinto H, Martins-Bessa A, Leitão JC, Bastos E: Interleukin- 6 gene $-174 \mathrm{G}>\mathrm{C}$ and $-636 \mathrm{G}>\mathrm{C}$ promoter polymorphisms and prostate cancer risk. Mol Biol Rep 2013, 40:449-455.

25. Yin YW, Sun QQ, Hu AM, Wang Q, Liu HL, Hou ZZ, Zeng YH, Xu RJ, Shi LB, Ma JB: Associations between interleukin- 6 gene -174 C/G and -572 C/G polymorphisms and the risk of gastric cancer: a meta-analysis. J Surg Oncol 2012, 106:987-993.

26. Yu KD, Di GH, Fan L, Chen AX, Yang C, Shao ZM: Lack of an association between a functional polymorphism in the interleukin- 6 gene promoter and breast cancer risk: a meta-analysis involving 25,703 subjects. Breast Cancer Res Treat 2010, 122:483-488.

27. Ma L, Zhao J, Li T, He Y, Wang J, Xie L, Qin X1, Li S: Association between Tumor necrosis factor-alpha gene polymorphisms and prostate cancer risk: a meta-analysis. Diagn Pathol 2014, 9:74.

28. Liu Y, Tang W, Wang J, Xie L, Li T, He Y, Qin X, Li S: Clinicopathological and prognostic significance of S100A4 overexpression in colorectal cancer: a meta-analysis. Diagn Pathol 2013, 8:181.

29. Xu Z, Yu L, Zhang X: Association between the hOGG1 Ser326Cys polymorphism and lung cancer susceptibility: a meta-analysis based on 22,475 subjects. Diagn Pathol 2013, 8:144.

\section{doi:10.1186/1746-1596-9-134}

Cite this article as: Wang et al:: Lack of association between a functional polymorphism (rs1800796) in the interleukin-6 gene promoter and lung cancer. Diagnostic Pathology 2014 9:134.

\section{Submit your next manuscript to BioMed Central and take full advantage of:}

- Convenient online submission

- Thorough peer review

- No space constraints or color figure charges

- Immediate publication on acceptance

- Inclusion in PubMed, CAS, Scopus and Google Scholar

- Research which is freely available for redistribution 